\title{
FROZEN FOOD CONSUMER'S PURCHASE INTENTIONS AND DECISIONS THROUGH E-COMMERCE IN THE GREATER JAKARTA RAGION
}

\author{
Maryanti Sitohang"), Suprehatin*), Andriyono Kilat Adhi") \\ ${ }^{*}$ Department of Agribusiness, Faculty of Economics and Management, IPB University \\ Jl. Agatis, Campus of IPB Darmaga Bogor 16680, Indonesia
}

\begin{abstract}
The rise of e-commerce provides consumers more opportunities to purchase agricultural and food products including frozen food. This study aims is to examine the effects of different factors on consumers' intention and decision on purchasing frozen food through e-commerce based on theory of planned behavior (TPB) and technology acceptance model (TAM). This study used the primary data from online survey of 200 respondents in Greater Jakarta who purchased frozen food through e-commerce. Data were analyzed using partial least squares-structural equation modelling (PLS-SEM). The results showed that perceived usefulness and perceived ease of use e-commerce have a positive influence on attitudes. Then attitudes, subjective norms, and behavior control had a significant positive effect on purchase intention. The results also confirmed that consumers' purchasing decisions on frozen food affecting by their purchase intention.
\end{abstract}

Keywords: : e-commerce, frozen food, purchase intention, TAM, TPB

\begin{abstract}
Abstrak: Munculnya e-commerce memberikan konsumen lebih banyak kesempatan untuk membeli produk pertanian dan makanan termasuk makanan beku. Penelitian ini bertujuan untuk menguji pengaruh berbagai faktor terhadap niat dan keputusan konsumen dalam membeli makanan beku melalui e-commerce berdasarkan teori perilaku terencana (TPB) dan model penerimaan teknologi (TAM). Penelitian ini menggunakan data primer dari survei online terhadap 200 responden di Jabodetabek yang membeli makanan beku melalui e-commerce. Analisis data menggunakan partial least squares-structural equation modeling (PLS-SEM). Hasil penelitian menunjukkan bahwa persepsi kegunaan dan kemudahan penggunaan e-commerce berpengaruh positif terhadap sikap. Kemudian sikap, norma subjektif, dan kontrol perilaku yang dirasakan berpengaruh positif signifikan terhadap niat beli. Hasil penelitian juga menegaskan bahwa keputusan pembelian konsumen pada makanan beku dipengaruhi oleh niat beli mereka.
\end{abstract}

Kata kunci: e-commerce, makanan beku, niat membeli, TAM, TPB

${ }^{1}$ Corresponding author:

Email: borusitohangmaryanti@gmail.com 


\section{INTRODUCTION}

Electronic commerce (e-commerce) continues to grow in Indonesia. Currently, the e-commerce market in Indonesia is the largest in Southeast Asia where about 90 percent of internet users in Indonesia have shopped online (Sirclo.com, 2020). The existence of e-commerce is revealed by both consumers (business to consumer) and business people (business to business) when conducting transactions (Mumtahana et al. 2017). The products offered by e-commerce are also increasingly diverse, from fashion products, cosmetics, medicines, electronics, travel services, and household appliances to food and agricultural products.

Based on the 2020 e-commerce statistics, food, beverages and groceries are the most sold products in 2019 , reaching 30.95 percent of the total businesses that are sampled for e-commerce (BPS, 2020). One of the food products that are widely sold through e-commerce is frozen food, processed semi-cooked food that is packaged and frozen with the aim of preserving food until it is ready to eat with long enough storage in the freezer (Tressler, 1957).

Nationally, the demand for frozen food in 2019 reaches 33.5 million tons, but only a third of it is able to be met by Indonesian frozen food producers (ARPI, 2019). Due to the Covid-19 pandemic, the total national consumption of frozen food is estimated to increase by $17 \%$ to around 11.58 million tons in 2020 (Qonita, 2021). This increase was caused by public awareness to gain food supplies during the increasingly high pandemic and restrictions on operating hours of shopping centers and traditional markets to prevent the spread of Covid-19. This encouraged frozen food business players to continue to develop both the type of product, the amount of production and marketing, including through e-commerce.

The existence of e-commerce provides greater opportunity for consumers to buy the products they need online. In the context of the Covid-19 pandemic, e-commerce plays a role in providing effective solutions for consumers to shop for their food needs without having to leave the house. The growing number of e-commerce offering a variety of products provides convenience for consumers by staying at home. On the other hand, the policy of limiting social activities or going outside during the Covid-19 pandemic also encourages consumers to shop online. This makes the shift in consumer behavior online shopping is increasing.

Based on empirical studies, there are several benefits of shopping online. These benefits include more detailed product information, easier comparison of quality and prices between stores, a more convenient information search and purchase process because it can be done anywhere and anytime, reliable, easy to do in transactions, as well as increasing consumer spending productivity (Lestari 2017; Yeo et al. 2017; Aref et al. 2019; Maia et al. 2018; Hasrini et al. 2017). Although e-commerce provides many benefits, there are still consumers who are hesitant or have problems shopping through e-commerce. For example, there are consumers who still doubt on the products offered by e-commerce. The influence of friends or family dissatisfied with online shopping can also influence online shopping decision. Because it is necessary to use technology such as smartphones, computers and internet networks, there are consumers experiencing problems in transacting through the e-commerce so they decide to continue shopping for food needs at the nearest market or store. For some consumers, shopping through e-commerce is a new thing for them so they still need adjustments in transaction procedures.

Based on this, many factors can influence consumer purchasing decisions using e-commerce, including buying frozen food. Many empirical studies have examined consumer purchasing decisions such as using the TPB approach developed by Ajzen (1991). Like other empirical studies using TPB (He et al. 2019; Piroth et al. 2020; Suleman 2018; Ilyas et al. 2020; Ranadive 2015; Nosi et al. 2019; Lee \& Ngoc 2010; Listyowati et al. 2020), subjective norm, behavioral control, and confirmed attitude factors influence consumers' intentions and decisions when shopping online.

In the TPB concept, purchasing decision is influenced by consumer intention where the intention is related to subjective norm, behavior control and attitude to behave (Ajzen, 1991). Beside using the TPB approach, this study also used the TAM approach because it related to the use of e-commerce utilizing internet technology and applications in shopping for frozen foods. TAM was used to capture consumer attituded in utilizing e-commerce through perceived usefulness and perceived ease of use in shopping for frozen food through e-commerce. The two approaches, namely TAM and TPB, were used to 
predict the intention and purchase decision of frozen food consumers through e-commerce more precisely. Through a combination of TAM and TPB approaches, Sulistiyarini (2012) confirmed that perceived ease of use and usefulness affected individual attitudes in using mobile banking. Furthermore, subjective attitude and norm have a strong influence on individual interest in using mobile banking (Sulistiyarini, 2012). The same procedures were done by Troise et al. (2020) in exploring behavior intention of the utilization of online food delivery services using TAM and TPB.

Based on this, in general, this study aimed to analyze the factors influencing the intention and purchase of frozen food through e-commerce using the TPB and TAM frameworks. Specifically, this study aimed to (1) analyze the effect of perceived usability, ease of use and subjective norm on consumer attitude in the use of e-commerce for online purchases, (2) analyze the effect of subjective norm, attitude on intention to buy frozen food through e-commerce, and behavior control, and (3) analyze the effect of intention on frozen food purchase decision through e-commerce.

\section{METHODS}

This research was conducted on respondents located in Jakarta, Bogor, Depok, Tangerang, and Bekasi (Jabodetabek). Jabodetabek is the center of economic development and growth, so it has good potential to develop consumer buying behavior through e-commerce. This research was conducted in June July 2021.

The type of data used in this study was primary data from 200 respondents in Jabodetabek. The respondent's criteria were respondents who had bought frozen food through e-commerce and were over 17 years old. Primary data were collected through the distribution of online questionnaires using Google forms. The Google form link was distributed to several WhatsApp Group networks followed by researchers. In addition, Instagram users who commented on e-commerce's social media or the e-commerce's website (such as Shopee, Tokopedia, OLX, GrabMart, SayurBox, Lazada, Go Mart, Happy Fresh and others) were contacted. They were asked to confirm whether they had purchased frozen food and were willing to fill out the questionnaire. Data collection was carried out in June-July 2021.
The data analysis method used was the Structural Equation Model Partial Least Squares (SEM-PLS), which was an alternative to SEM. Ghozali (2014) explains that SEM is an analytical tool that provides the ability to perform path analysis with latent variables. SEM has higher flexibility for researchers to link theory and data. PLS can test structural models (relationships between latent variables) and measurement models (relationships between latent variables and indicators) simultaneously.

In the use of the TAM and TPB frameworks, there were seven latent variables in this study, namely perceived usefulness, perceived ease of use, attitude toward using, subjective norm, perception of behavior control (perceived behavior control), intention and decision. Of the seven latent variables, the endogenous variables were attitude, intention, and purchase decision (Figure $1)$.

SEM-PLS analysis consists of two sub-models, namely the outer model and the inner model. The outer model is how each indicator block relates to its latent variable. The inner model describes the relationship between latent variables based on substantive theory. PLS can also analyze constructs formed with reflective indicators and formative indicators. This study used a reflective indicator model approach, namely a condition where indicators could reflect latent variables. The reflective indicator model required that the indicators be correlated with each other. If there was a change from one indicator it would result in changes in other indicators in the same direction, but would not result in changing the meaning of the latent variable (Monecke \& Leisch, 2012).

The reflective measurement model stage (outer model) wasevaluatedusingthreetestmethods, namelycovergent validity, discriminant validity and composite reliability. First, convergent validity was assessed based on the correlation between the item score/component score and the construct score calculated by PLS. Data could be said to be valid if it had a loading score more than 0.7 . If there was an indicator with a value less than 0.7 then the indicator had to be deleted and data validation was carried out. Second, discriminant validity was assessed based on cross loading measurements with constructs. Another method to assess discriminant validity was by comparing the square root of average variance extracted (AVE) value. If the square root value of the AVE for each construct was greater than the correlation 
value between the construct and other constructs in the model, it was said to have a good discriminant validity value (Fornell and Larcker, 1981 in Ghozali, 2014). Furthermore, the recommended AVE value had to be greater than 0.50 . Third, composite reliability was used to measure the reliability of the construct of the indicator block, the construct was declared reliable if the composite reliability value was of more than 0.7. Cronbach's alpha could also be used to measure construct reliability, namely if Cronbach's alpha was more than 0.6 (Abdillah and Hartono, 2017).

Testing of the structural model (inner model) was done by looking at the value of R-Square $\left(\mathrm{R}^{2}\right)$ which was the goodness-fit test of the model. The second test was conducted by noticing the significance of the effect of the independent variable on the dependent variable by looking at the parameter coefficient values and the statistical significance value of $t$, which was obtained by the bootstrapping procedure. The results on the t-test and significance were said to be significant if they had a T-statistic value greater than 1.96 (T-table value for $5 \%$ level) (Ghozali, 2017).

\section{RESULTS}

\section{Characteristics of Respondents}

Research respondents were consumers who had purchased frozen food through e-commerce in the Jabotabek area. Of the 200 respondents, most of the respondents belonged to the age category of 20-30 years $(71.5 \%)$, female gender $(82.5 \%)$ (Table 1$)$. The majority of respondents lived in Jakarta (45\%), were not married yet (70\%), having a bachelor's degree (71\%), and working in private companies (29.5\%) (Table 1). The majority of those shopping for frozen food through e-commerce had a monthly income of IDR 3,000,000 IDR $5,000,000$, followed by respondents with a monthly income of IDR 5,000,000 - IDR 10,000,000. This shows that the purchase of frozen food through e-commerce was carried out by upper-middle consumers. The number of people who lived in the same house as the respondent was dominated by the family category with 1-3 members (Table 1).

\section{Buying Behavior of Frozen Food Consumers through E-commerce}

The main reasons respondents bought frozen food through e-commerce were more efficient shopping time, easy payments, lots of promotions or discount vouchers, and could be done from home, especially during the Covid-19 pandemic. Types of frozen foods mostly purchased by respondents were nuggets $(65 \%$ of respondents), sausages $(60 \%)$, meatballs $(55.5 \%)$, fried potatoes $(43.5 \%)$, and chicken meat (30.5\%). In general, they carried out the process of buying frozen food through e-commerce on their own, from ordering to payment using a smartphone. Respondents using more than one e-commerce to buy frozen food were 113 people (56.5\%) and other 87 people (43.5\%) used only one e-commerce.

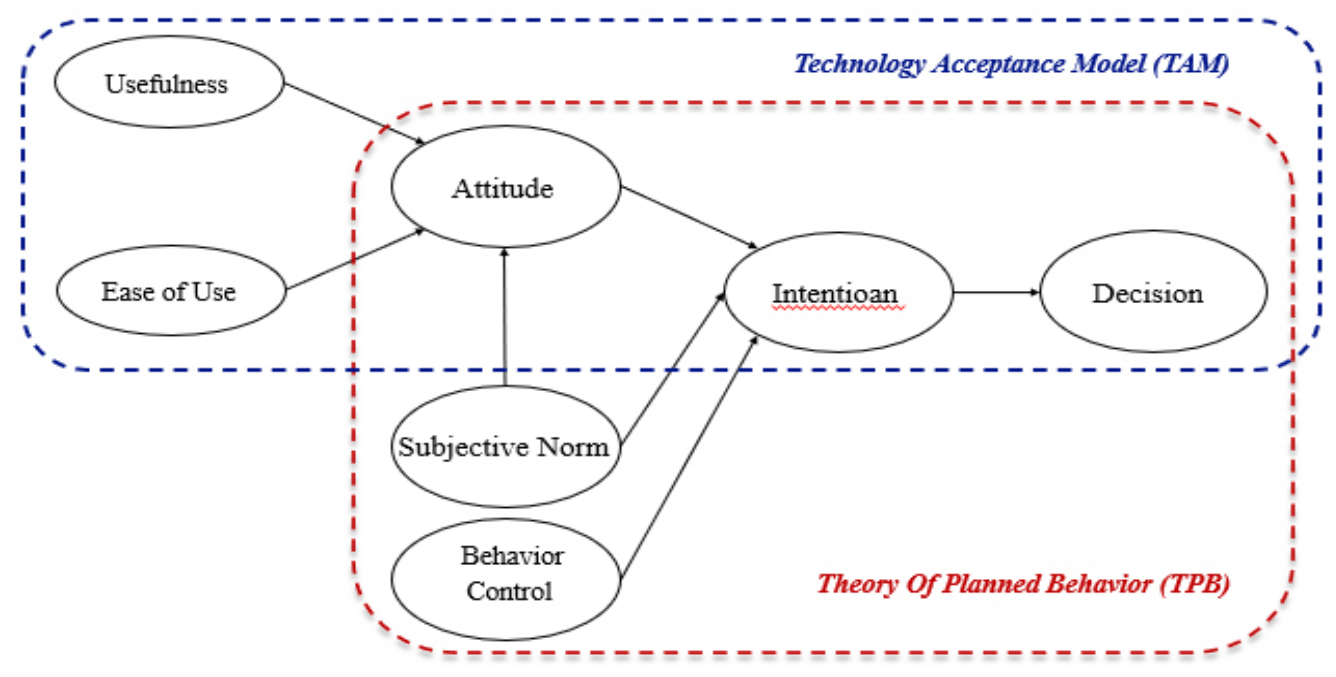

Figure 1. Research framework 
The frequencies of purchasing frozen food through e-commerce mostly done by respondents were, namely once per few months (72 respondents), followed by 2-3 times a month (58 people), once a month (44 respondents), once a week (17 people), and every two months ( 9 respondents). From the purchase of frozen food, most of the respondents (113 respondents) spent 5 percent of their income to buy frozen food.

\section{Factors Influencing Consumer Intentions and Decisions to Purchase Frozen Food through E-commerce}

This study used SEM-PLS to analyze the factors influencing consumer purchase intentions and decisions of frozen food through e-commerce. The evaluation of the model was carried out both for the evaluation of the measurement model (outer model) which included testing of convergent validity, discriminant validity and composite reliability, as well as evaluation of the structural model (inner model). First, in the evaluation of the outer model (based on convergent validity testing), this study used 26 indicators meeting a loading factor of more than 0.7. Discriminant validity testing showed that all latent variables had an AVE value above 0.50 (Table 2), so all variables were declared valid. The construct reliability test revealed that all variables in this study were declared reliable because they had composite reliability and Cronbach's alpha values (Table 2).

Second, the evaluation of the inner model showed that the $\mathrm{R}^{2}$ values for each dependent variable in this study were 0.56 of attitude, 0.59 of purchase intention and 0.45 of purchase decision, respectively. On the intention variable with $R^{2}$ of 0.59 , the variability of the purchase intention construct that could be explained by the variables included in the model, namely subjective norm, behavioral control and attitude towards use by 59 percent, while 41 percent others were explained by other variables outside the model. The significance test results of the effect of the independent variables on the dependent variables using the bootstrapping procedure can be seen in Table 3 .

Table 1. Characteristics of research respondents

\begin{tabular}{lcc}
\hline Characteristics & Category with Highest Percentage & Percentage $(\mathrm{n}=200)$ \\
\hline Age & $20-30$ year old & 71.5 \\
Gender & Female & 82.5 \\
Domicile & Jakarta & 45.0 \\
Educational degree & Bachelor degree & 71.0 \\
Marriage status & No married yet & 70.0 \\
Occupation & Private company employee & 29.5 \\
Income per month & $3-5$ millions & 38.0 \\
Number of family members & $1-3$ persons & 47.0 \\
\hline
\end{tabular}

Table 2. Outer model evaluation results

\begin{tabular}{lccc}
\hline Variable & Cronbach's Alpha (CA) & Average Variance Extracted (AVE) & Composite Reliability (CR) \\
\hline Subjective Norm & 0.885 & 0.685 & 0.916 \\
Attitude & 0.770 & 0.593 & 0.853 \\
Usefulness & 0.819 & 0.650 & 0.881 \\
Ease of Use & 0.606 & 0.717 & 0.835 \\
Behavior Control & 0.632 & 0.571 & 0.800 \\
Intention & 0.815 & 0.730 & 0.890 \\
Decision & 0.814 & 0.561 & 0.865 \\
\hline
\end{tabular}


Table 3. Output of bootstrapping

\begin{tabular}{lcccc}
\hline Influence Path & Coefficient & T-stat & P-value & Hypothesis \\
\hline Usefulness $\rightarrow$ Attitude & 0.378 & 4.940 & $0.000^{*}$ & Confirmed \\
Ease of Use $\rightarrow$ Attitude & 0.190 & 2.410 & $0.016^{* *}$ & Confirmed \\
Subjective Norm $\rightarrow$ Attitude & 0.326 & 5.017 & $0.000^{*}$ & Confirmed \\
Subjective Norm $\rightarrow$ Intention & 0.334 & 5.763 & $0.000^{*}$ & Confirmed \\
Behavior Control $\rightarrow$ Intention & 0.175 & 2.809 & $0.005^{*}$ & Confirmed \\
Attitude $\rightarrow$ Intention & 0.389 & 5.752 & $0.000^{*}$ & Confirmed \\
Intention $\rightarrow$ Decision & 0.668 & 16.717 & $0.000^{*}$ & Confirmed \\
\hline
\end{tabular}

Note: *significant at $\alpha=1 \%, * *$ significant at $\alpha=5 \%$

Overall, the results showed that all the variables from the TAM and TPB frameworks used were confirmed in influencing the consumer's intention and purchase decision of frozen food through e-commerce (Table 3). The TAM components, namely perceived usefulness and perceived ease of use, were confirmed to affect attitude. Furthermore, the components of TAM and TPB, namely attitude toward using, subjective norm, and perceived behavior control had been confirmed to influence intention. Finally, confirmed intention influenced frozen food consumer purchasing decision through e-commerce.

First, based on Table 3, it can be seen that usability, ease of use and subjective norm in shopping through e-commerce had a positive and significant relationship with attitude to using e-commerce. This means that if consumers felt the benefits of buying frozen food through e-commerce, the easier it was to use e-commerce, the better the attitude of consumers to buying frozen food through e-commerce. Perceived usefulness and ease of use are TAM components influencing consumer attitude to take an action when able and easy to apply a technology (Davis, 1989). On the other hand, the significant effect of subjective norm showed that the more consumers trust and were motivated by the opinions of those closest to them (family, friends, and other experienced people) buying frozen food through e-commerce, the stronger the consumer's attitude to buying frozen food through the e-commerce. This study is in accordance with (Hansen et al. 2004; Pirot et al. 2020). stating that subjective norm has a relationship with one's attitude in adopting e-commerce.

Second, Table 3 shows that there were three factors significantly influencing the intention to buy frozen food through e-commerce, namely subjective norm, attitude, and behavior control. This shows that the three confirmed TPB component variables affected the consumer's purchase intention of frozen food through e-commerce. Subjective norm had a positive effect on intention, meaning that the more consumers believed from the opinions of the closest people (family, friends, and other experienced people) to buy frozen food through e-commerce, the stronger the consumer's intention to buy frozen food through e-commerce. Questionnaire statements contained in the subjective norm in this study indicated that respondents' answers had a positive response to people they considered important such as family, friends, and other people having experience in buying frozen food through e-commerce. These results are in accordance with Renadive's research (2015), suggesting that subjective norm has a significant influence on consumer intentions to shop at online grocery.

On the other hand, attitude had a positive effect on intention, meaning that the better the consumer's attitude in using e-commerce applications for purchasing frozen food online, the stronger the intention to buy frozen food through e-commerce. This is in line with the research of Chunxia and Ruihan (2016), suggesting that consumer attitude in China in using e-commerce affects the intention to shop for fresh agricultural products online. Furthermore, behavior control had a positive effect on intention, meaning that the more consumers were able to take action on purchasing frozen food through e-commerce under behavior control, the stronger the intention to buy frozen food through e-commerce. The results of this study are in accordance with the research of Lee \& Ngoc (2010), finding that behavior control is a variable strongly influencing consumers' purchase intention in shopping online.

Table 3 also shows that purchase intention had a positive and significant relationship to frozen food purchase decision through e-commerce. The positive influence of the purchase intention variable could 
explain that the more consumers had the intention to buy frozen food through e-commerce, the more confident consumer would make the decision to buy frozen food through e-commerce. This is in line with the research of Listyowati et al. (2020), revealing that consumer intention influences consumer decision to purchase vegetables and fruit online.

\section{Managerial Implications}

The results of the analysis of the factors influencing the intention and purchase of frozen food through e-commerce can be useful as information for e-commerce companies in making decisions. Based on this, the managerial implication of this research is that e-commerce companies can use promotions through people who are considered important by consumers such as family, friends, and other closest people to consumers in encouraging and stimulating consumers to purchase frozen food through e-commerce. Furthermore, e-commerce companies can offer convenience in transacting through e-commerce such as providing information about shopping procedures, providing easy-to-understand explanations for consumers on the features displayed in their sales, and accurate. E-commerce companies can also perform good service by using newsletters, product upsells, ad retargeting, referral marketing, and abandoned cart e-mails, as well as innovating so that consumers feel safe, comfortable, profitable in enjoying shopping through e-commerce.

\section{CONCLUSIONS AND RECOMMENDATIONS}

\section{Conclusions}

The conclusions from the results of this study are (1) perceived usefulness, ease of use and subjective norm had a positive and significant influence on attitude to using e-commerce, (2) attitude, subjective norm, and behavior control had a positive and significant influence on frozen food purchase intention through e-commerce, and (3) purchase intention had a positive and significant influence on frozen food purchase decision through e-commerce.

\section{Recommendations}

The advice given in this study is that further research can add things that have not been covered in this study because there are still many other relevant factors influencing the intention and purchasing decision of frozen food consumers through e-commerce, such as safety, price, quality, and etc. This follow-up research can also be carried out to confirm the TAM and TPB frameworks in different research areas or in certain consumer segments. For further research, data collection may consider using the probability sampling method to accommodate the limitations of this study.

\section{REFERENCES}

Abdillah W, Hartono J. 2015. Partial Least Square (PLS) Alternatif Structural Equation Modeling (SEM) dalam Penelitian Bisnis. Yogyakarta: Penerbit Andi.

Ajzen. 1991. The Theory of Planned Behavior. New York: Open University. https://doi. org/10.1016/0749-5978(91)90020-T

Aref MM, Okasha EA. 2019. Evaluating the online shopping behavior among egyptian college educated community. Review of Economics and Political Science 5(1): 21-37. https://doi. org/10.1108/REPS-10-2018-0013

[BPS] Badan Pusat Statistik. 2020. Statistik E-commerce 2020. Jakarta: Badan Pusat Statistik.

Chunxia WU, Ruihan LIU. 2016. A study on consumers' intentions and attitudes to fresh agricultural products for online shopping in China. International Journal of Simulation Systems, Science \& Technology 17(45).

Davis FD. 1989. A Technology of Acceptance Model for Empirically Testing New-End User Information System:Theory andResults. Doctoral dissertation. Massachusetts: Sloan School of Management, Massachusets Institute of Technology.

Ghozali I. 2014. Structural Equation Modeling: Metode Alternatif dengan Partial Least Square (PLS). $E d$ ke- 4. Semarang: Universitas Diponegoro.

Ghozali I. 2017. Model Persamaan Struktural Konsep dan Aplikasi dengan Program AMOS 24.0. Update Bayesian SEM. Semarang: Universitas Diponegoro.

Hansen T. 2008. Consumer values, the theory of planned behaviour and online grocery shopping. International Journal of Consumer Studies 32(2): 128-137.https://doi.org/10.1111/j.14706431.2007.00655.x

Hasrini S, Aditya PS. 2017. Faktor-faktor yang memengaruhi minat beli pangan organik melalui situs online. Jurnal Manajemen \& Agribisnis 
14(1): 54-64. https://doi.org/10.17358/ jma.14.1.54

He Z, Han G, Cheng TCE, Fan B, Dong J. 2019. Evolutionary food quality and location strategies for restaurants in competitive online-to-offline food ordering and delivery markets: an agentbased approach. International Journal of Production Economics 215: 61-72. https://doi. org/10.1016/j.ijpe.2018.05.008

Ilyas A, Zaman KM. 2020. An evaluation of online students' persistence intentions. Asian Association of Open Universities Journal 15(2): 207-222. https://doi.org/10.1108/AAOUJ-112019-0053

Lestari SA. 2017. Analisis faktor-faktor yang mempengaruhi keputusan belanja online di Yogyakarta: PVT Model. Disertasi. Jogja: Universitas Gadjah Mada.

Lee SH, Ngoc HTB. 2010. Investigating the online shopping intention of vietnamese student an extension of theory planned behavior world transaction of engineering and technology education. 8(4): 471-476.

Listyowati AE, Suryantini A, Irham. 2020. Faktorfaktor yang mempengaruhi niat dan keputusan konsumen membeli sayuran dan buah secara online. Jurnal Kawistara 10(1): 66-76. https:// doi.org/10.22146/kawistara.41891

Maia C, Lunardi G, Longaray A, Munhoz P. 2018. Factors and characteristics that influence consumers participation in social commerce. Revista de Gestão 25(2): 2177-8736. https://doi. org/10.1108/REGE-03-2018-031

Monecke A, Leisch F. 2012. SEM PLS: structural equation modeling using partial least square. Journal of Statistic Software 48(2012): 1-32. https://doi.org/10.18637/jss.v048.i03

Mumtahana AH, Nita S, Tito WA. 2017. Pemanfaatan web e-commerce untuk meningkatkan strategi pemasaran. Jurnal Ilmu Komputer dan Informatika 3(1): 6-15.https://doi.org/10.23917/ khif.v3i1.3309

Nosi C, Lamberto Z, Riccardo R, Cristiano C. 2019.
Sustainable consumption in organic food buying behavior: the case of quinoa. British Food Journal 122(3): 976-994. https://doi.org/10.1108/BFJ09-2019-0745

Piroth P, Ritter MS, Rueger-Muck E. 2020. Online grocery shopping adoption: do personality traits matter?. British Food Journal 122 (3): 957-975. https://doi.org/10.1108/BFJ-08-2019-0631

Qonita A. 2021. Bisnis Makanan Beku, Menghangat di Era Corona. https://www.alinea.id/bisnis/bisnismakanan-beku-menghangat-di-era-coronab2cxM90B3. [2021 April 29].

Ranadive A. 2015. An empirical study on the online grocery shopping intentions of consumers in vadodara city. International Journal of Management and Social Sciences Research. 4(3): 8-14.

Sirclo.com. 2020. Menilik Tren Perkembangan E-commerce Indonesia. https://www.sirclo. com/menilik-tren-perkembangan-e-commerceindonesia-di-2020/. [2020 Aug 19].

Suleman D. 2018. Faktor penentu keputusan konsumen indonesia memilih tempat belanja disebuah e-commerce. Jurnal JDM 1(2):1-9.

Sulistiyarini S. 2012. Pengaruh minat individu terhadap penggunaan mobile banking: model kombinasi technology acceptance model (tam) dan theory of planned behavior (tpb). Jurnal Mahasiswa FEB Universitas Brawijaya 1(2):1-20.

Troise C, O’Driscoll A, Tani M dan Prisco A. 2020. Online food delivery services and behavioural intention - a test of an integrated tam and tpb framework. British Food Journal 123(2): 664 683. https://doi.org/10.1108/BFJ-05-2020-0418

Tressler DK, dan Evers. 1957. The Freezing Preservation of Foods. Westport Connecticut: The AVI Publishing Company.

Yeo VCS, SK Goh, Rezaei S. 2017. Consumer Experiences, attitude and behavioral intention toward online food delivery (ofd) services. Journal of Retailing and Consumer Services 35: $\quad 150-162 . \quad$ https://doi.org/10.1016/j. jretconser.2016.12.013 